By Zhide XU, Sumito NISHIO, Masaru IKAME, Magoshiro KUWABARA,

In this research an assist-injector was newly developed to improve the $\mathrm{CO}$, THC and smoke emissions from a marine diesel engine fueled with vegetable oil. The effect of pre-injection and after-injection on the combustion characteristics and the exhaust emissions were investigated by engine test bench experiments. Results show that the assist-injector is effective for $\mathrm{CO}$, THC and smoke emissions reduction. The reduction efficiency of $\mathrm{CO}$, THC and smoke is about $30 \%$ with after-injection, and is over $50 \%$ with pre-injection.

Key Words: Vegetable oil, Marine diesel engine, Assist-injector, Pre-injection and After-injection

1. はじめに

現在, 地球温暖化対策が重要な課題となっており, バイオ燃料使用による二酸化炭素 $\left(\mathrm{CO}_{2}\right)$ 排出削減が 期待されている，著者らは，バイオ燃料をエステル 化処理せず舶用燃料として利用することに着目し， 菜種油，パーム油などの植物油を舶用ディーゼル機 関に適用し，その燃焼・排ガス特性を明らかにした ${ }^{1),}$ 2)，3）。植物油は軽油・A 重油に比べて粘度が高く, 蒸発性が低く，低負荷での燃焼が悪いため一酸化炭 素 (CO) ，全炭化水素分（THC）濃度およびスモー ク值が高く, 対策が必要であることが分かっている. 石油系燃料での燃焼改善と有害排ガス低減をするに は，コモンレール式燃料噴射装置が大きく寄与して (る. 小川ら ${ }^{4)}$ はアフター噴射によるディーゼルの

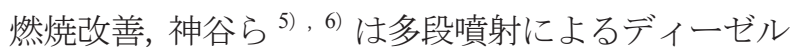
の有害排ガス低減などの研究を行った。しかし，コ モンレール式燃料噴射装置を用いて, 植物油への燃 焼改善と有害排ガス低減に関する研究例は少なく, 不明点は多い. 本研究では, 植物油燃焼一の燃料噴 射制御技術として小型コモンレール式燃料噴射装置 と機械式燃料噴射装置を組み合わせた新しい燃料噴 射装置（アシスト噴射と呼ぶ）の開発に取り組み, アシスト噴射による低負荷での植物油の CO, THC 及びスモークの低減を試みた。 その結果を報告する。

\begin{tabular}{lll}
\hline$*$ & 原稿受付 & 平成 22 年 9 月 15 日. \\
$* *$ & 正会員 & 独) 海上技術安全研究所 (三鷹市新川6-38-1). \\
$* * *$ & & (独) 海上技術安全研究所 (二鷹市新川6-38-1).
\end{tabular}

2. アシスト噴射の機構

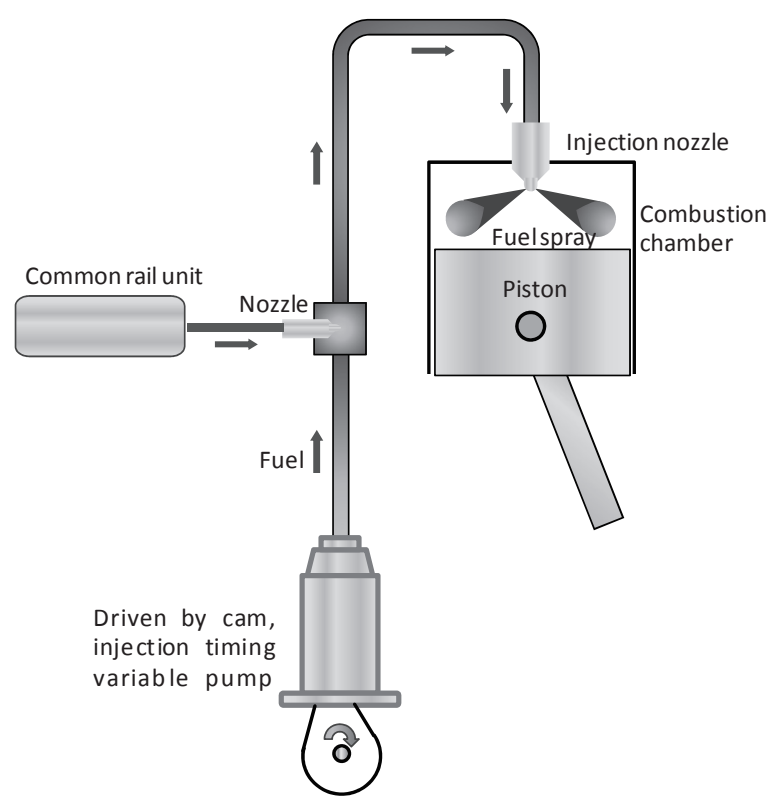

Fig. 1 Assist-injector

植物油の低負荷での燃焼を改善するためには，燃 料噴射の高圧化や噴射時期，噴射パターンの変更な どが考えられる. 自動車用ディーゼル機関において は，コモンレールを用いた電子制御然料噴射装置が 一般的になっている。しかし，これを舶用ディーゼ ル機関に適用しようとすると, 1 回当たりの噴射量が 多いため, コモンレールや加圧ポンプの大型化とい う問題が生じ，大幅なエンジン改造が必要になる。 そこで，Fig.1に示寸ように，機械式燃料噴射装置に 
小型コモンレール式燃料噴射装置を付加することで, 安価に，また既存のエンジンに比較的容易に適用で きる燃料噴射装置を開発した。既存の機械式燃料噴 射（以下メイン噴射と略記）に電子制御噴射を加え ることから，アシスト噴射と命名した（以下アシス 卜噴射と略記）。

メイン噴射する機械式燃料噴射ポンプのプランジヤ 一径は $20 \mathrm{~mm}$ で, ストロークは $18 \mathrm{~mm}$ である. 燃料噴射ノ ズルは $\phi 0.32 \times 7$ 穴, 開弁圧は約 $26 \mathrm{MPa}$ である.これ に対して, アシスト噴射するコモンレール式然料噴射 装置は, 6 気筒総排気量約 15.7 リットルの自動車用デ イーゼルエンジンの最高圧力 $180 \mathrm{MPa}$ のコモンレー ルを使用している.

Fig.2 にアシスト噴射による噴射圧の調整を示寸. Fig.3 にアシスト噴射のパターンを示寸. Fig.2, Fig.3 に示すように, アシスト噴射の特長は, エンジン回 転数と負荷率に依存せず噴射圧力や噴射時期を制御 することが可能である。また，プレ噴射，アフター 噴射等, 多様な燃料噴射パターンが可能である. ア シスト噴射のメリットとしては, (1)小型化が可能,

(2)自動車用の電子制御噴射装置の活用が可能 (安価), (3)比較的改造が少なく既存のエンジンに適用が容易 である。

\section{3. 実験装置及び実験方法}

実験装置を Fig.4 に示す. 主な構成は, 舶用中速 4 ストロークディーゼル機関(松井鉄工所製, MU323DGSC 型, 主要目を Table1 に示す), アシスト 噴射装置及び排ガス計測装置から成る。実験方法は, 菜種油 50\% と A 重油 50\%の混合油を使って, 舶用特 性に従って, 負荷率 $25 \%$ （機関出力: $64.5 \mathrm{~kW}$, 機関 回転数 : 265rpm) でアシスト噴射のタイミングと噴 射量を変えて実験を行った。

排ガス計測では燃焼ガス分析計(テストー製, 350XL 型)を用いて, $\mathrm{NOx}, \mathrm{CO}, \mathrm{O}_{2}, \mathrm{CO}_{2}$ 濃度を計 測した。スモーク值(污染度\%)の計測は，JIS D 8004 に準拠した光反射式スモークメータ(SOKKEN 製,

GSM-3 型)を使用した. 本エンジンのスモーク值は低 いため, 通常の 5 倍の体積の吸引を 5 回実施し, そ の平均值を計測值とした. 排ガス中の THC の計測は 全炭化水素濃度計測装置(日本サ一モ製, 51C-LT/HT 型)を使用した。サンプルガスの加熱導管温度は $191^{\circ} \mathrm{C}$ 設定した.

実験に際し，機関を各運転条件に設定後，30 分以 上運転し, 機関の状態が静定した後, 筒内圧データ をクランク角度 0.5 度間隔で収集するとともに排ガ ス計測を実施した。

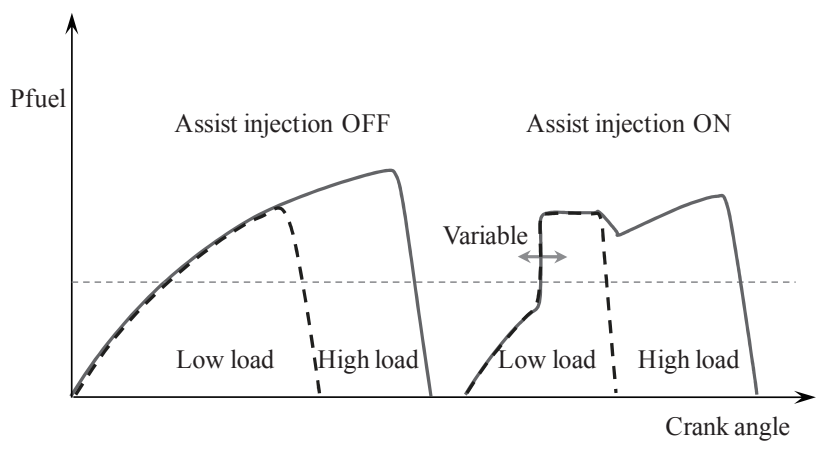

Fig. 2 Pressure control of assist injection

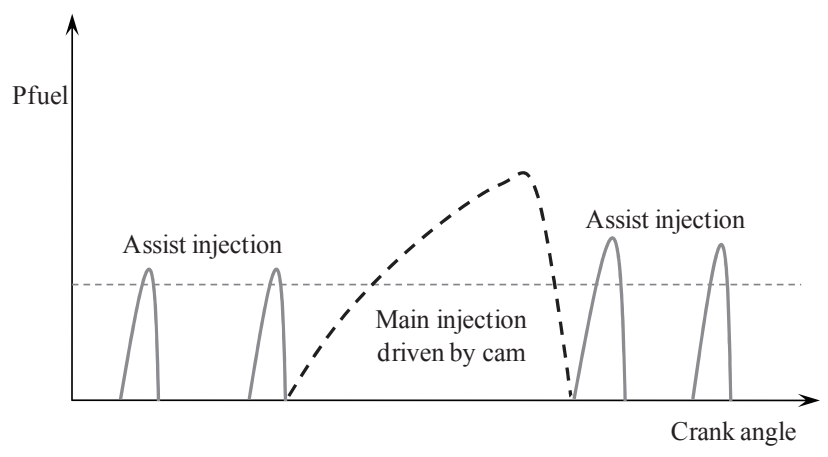

Fig. 3 Assist injection pattern

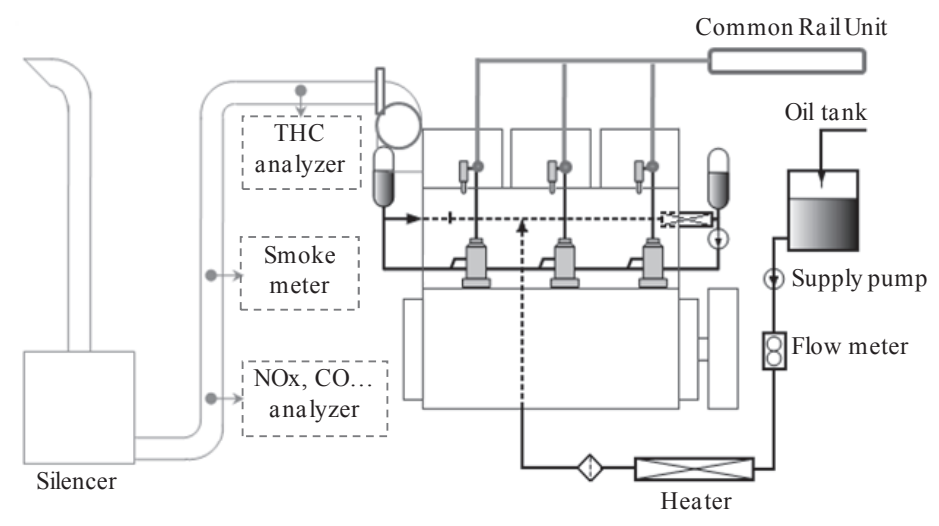

Fig. 4 Experimental setup

Table 1 Specifications of test engine

\begin{tabular}{|l|l|}
\hline Engine name & MU323DGSC \\
\hline Engine type & $\begin{array}{l}4 \text { stroke exhaust turbocharged } \\
\text { direct injection type }\end{array}$ \\
\hline Cylinder number & 3 \\
\hline Cylinder diameter & $230 \mathrm{~mm}$ \\
\hline Stroke & $380 \mathrm{~mm}$ \\
\hline Engine maximum output & $257.4 \mathrm{~kW}$ \\
\hline Engine maximum speed & $420 \mathrm{rpm}$ \\
\hline Mean effective pressure & $1.55 \mathrm{MPa}$ \\
\hline
\end{tabular}




\section{4. 実験結果及び考察}

\section{1 アシスト噴射による排ガス及び燃焼改善効果}

Fig. 5 に負荷率 $25 \%$ （機関出力： $64.5 \mathrm{~kW}$ ，機関回転 数 : 265rpm）で, メイン噴射の噴射タイミングを BTDC10 に設定し，アシスト噴射無し(図中 Assist Injection OFF)とアシスト噴射有り(図中 Pre-injection $\mathrm{ON}$ と After-injection $\mathrm{ON}$ )での $\mathrm{CO}, \mathrm{THC}$, スモーク およびNOx 計測結果を示寸. ここでアシスト噴射条 件は，プレ噴射 : $\mathrm{BTDC} 20^{\circ}$ ，噴射期間 $1.5 \mathrm{~ms}$ （出力換 算で約 $25 \%$ 負荷率の噴射量の $1.5 \%$ 相当）; アフター 噴射 : ATDC $10^{\circ}$ ，噴射期間 $2.5 \mathrm{~ms}$ (出力換算で約 $25 \%$ 負荷率の噴射量の $6 \%$ 相当）とした. アシスト噴射に よって, $\mathrm{CO}, \mathrm{THC}$ 及びスモークともに減少しており, 減少幅はアフター噴射効果約 $30 \%$, プレ噴射効果 $50 \%$ 以上である.アシスト噴射は低負荷での植物油 の $\mathrm{CO}, \mathrm{THC}$ 及びスモークの低減に効果があると判 断できる. NOxについては，プレ噴射の場合約 $15 \%$ 増え，アフター噴射の場合約 $15 \%$ 減った。 また，同 図に示したプレ噴射とアフター噴射を両方使用した 結果（このときメイン噴射は BTDC7に設定）は, NOx を抑えつつ, CO, THC 及びスモークの低減が できた。 これはプレ噴射とアフター噴射の相乗効果 によるものと考えられる.

排ガス計測の結果を解析寸る為に Fig.6 と Fig.7 にア シスト噴射無しと有りでの筒内圧 $(\mathrm{P})$, 燃料噴射圧

（Pfuel）及び筒内圧から算出した筒内温度（T）と熱 発生率 $(\mathrm{dQ} / \mathrm{d} \theta)$ を示す. プレ噴射の場合, 着火が早く, 圧縮終点圧・温度と最高筒内圧・温度ともに高くなっ ている.これはプレ噴射した燃料が先に燃焼すること により, 筒内温度が約 $100^{\circ} \mathrm{C}$ 上昇し, メイン噴射時の 筒内雾囲気が改善され，良い燃焼ができたと考えられ る. プレ噴射の場合に NOx が高く, CO, THC 及びス モークが低く出るのはこれが原因と考えられる. アフ ター噴射の場合, メイン噴射量が減少した分熱発生率 が低下し, 筒内圧・温度は低くなっている. その後ア フター噴射された燃料が再び燃焼している. アフター 噴射による CO, THC 及びスモークの低減原因につい て, 小川らはメイン噴射量の減少によるスモーク生成 量の抑制とアフター噴射の擋乱効果及びスモークの再 燃焼にあると報告している ${ }^{4)}$. 今回の結果もこのよう な原因と考える. NOx の減少はアフター噴射によるタ イミングリタード効果によるものと考えられる.

なお，低負荷で燃料噴射圧が低くなっており，高 粘度の植物油の噴霧・燃焼に影響を与えると考えら れる。 そのため，アシスト噴射とメイン噴射を同期 させ，最高燃料噴射圧を約 $40 \mathrm{MPa}$ から約 $60 \mathrm{MPa}$ に

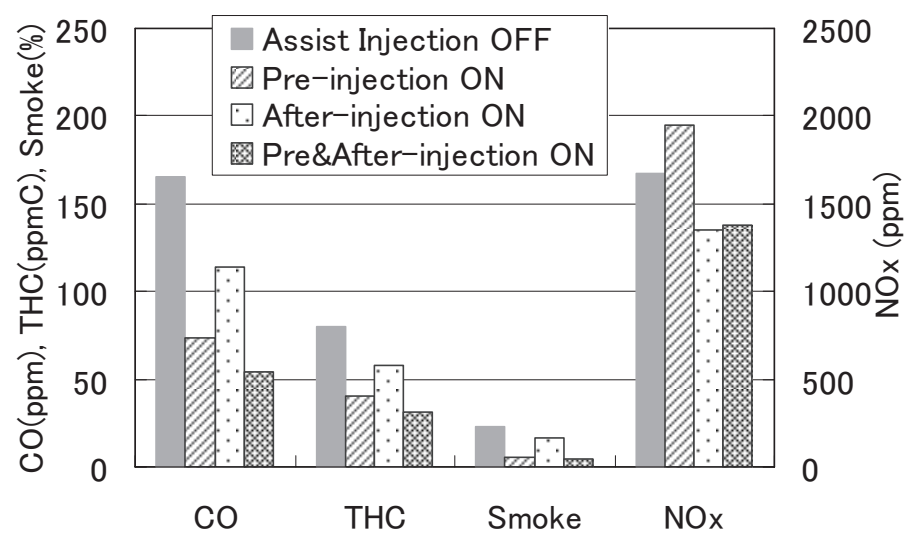

Fig. 5 CO, THC, Smoke and NOx vs. Assist Injection ON / OFF

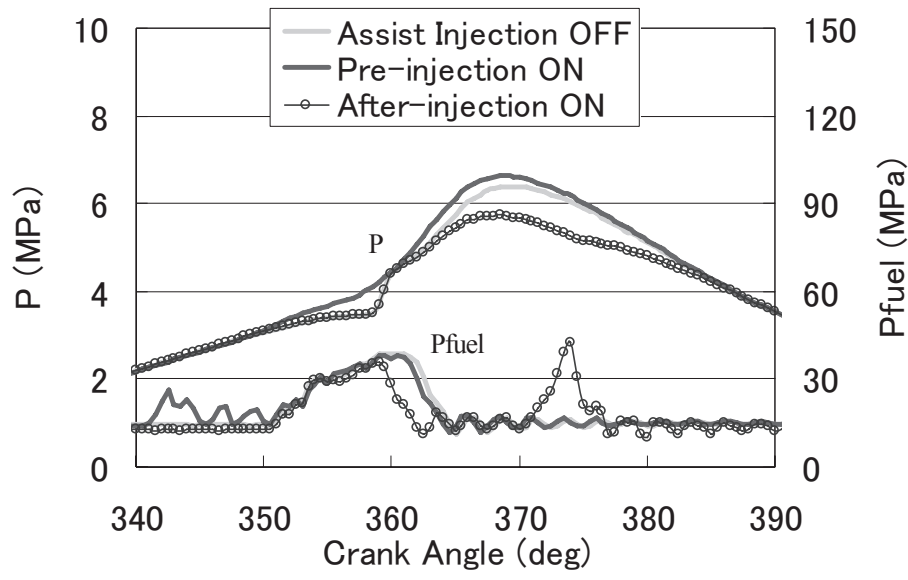

Fig. 6 P and Pfuel vs. Assist Injection ON / OFF

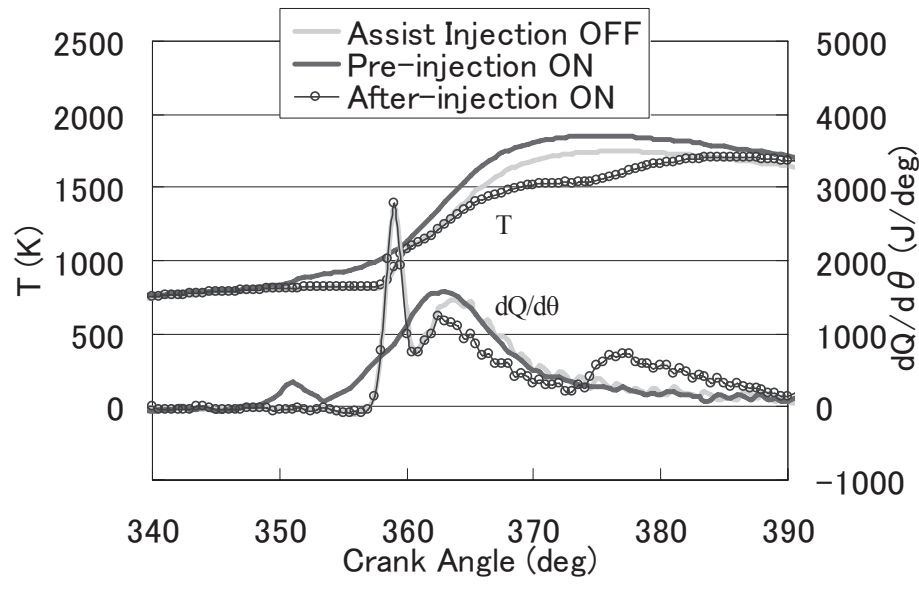

Fig. $7 \mathrm{~T}$ and $\mathrm{dQ} / \mathrm{d} \theta$ vs. Assist Injection $\mathrm{ON} / \mathrm{OFF}$

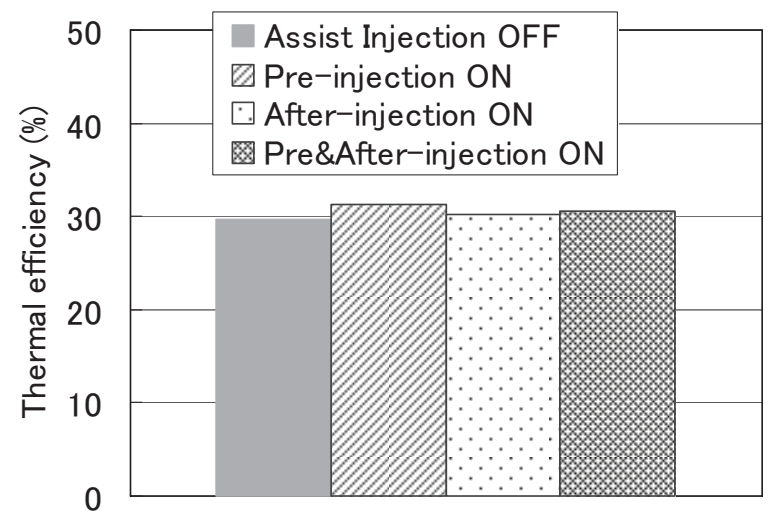

Fig. 8 Thermal efficiency 
アップして, 排ガス及び然焼改善効果についても調ベ たが, 実験を行った範囲ではプレ噴射とアフター噴射 ほどの改善効果は認められなかった。

Fig.8 にアシスト噴射無しとアシスト噴射有りでの 熱効率を示す。アシスト噴射無しょりアシスト噴射 有りの場合, 熱効率が若干増え, A 重油並みの約 31\% となっている.

\section{2 改善効果におよぼすアシスト噴射期間(量) の影響}

Fig.9 と Fig.10にプレ噴射とアフター噴射の噴射期間

（量）による改善効果への影響を示寸．ここでアシス 卜噴射期間（量）は，1.5ms（出力換算で約 $25 \%$ 負荷 率の噴射量の $1.5 \%$ 相当）, $2.0 \mathrm{~ms}$ （出力換算で約 $25 \%$ 負荷率の噴射量の $3 \%$ 相当）, $2.5 \mathrm{~ms}$ （出力換算で約 $25 \%$ 負荷率の噴射量の $6 \%$ 相当）とした.

NOx については，プレ噴射の場合，噴射量によらず ほぼ一定で，アフター噴射の場合，噴射量が多いほど 減少している.

CO，THC 及びスモークについては，プレ噴射の場 合，噴射量が少ないほうが望ましく，アフター噴射の 場合, 噴射量が多いほうが効果的である.

\section{3 改善効果におよぼすアシスト噴射時期の影響}

Fig.11 と Fig.12 にプレ噴射とアフター噴射の噴射タ イミングによる改善効果への影響を示す。

NOxについては, プレ噴射の場合，噴射タイミング によらずほぼ一定で，アフタ一噴射の場合，噴射タイ ミングが遅いほど減少している.

$\mathrm{CO}$, THC 及びスモークについては，プレ噴射の場 合, BTDC $20^{\circ}$ 以内でメイン噴射から離すのが効果的で, アフター噴射の場合, メイン噴射と約 $10^{\circ}$ 離れている ATDC10が望ましい.

\section{5. まとめ}

新たに開発したアシスト噴射により，低負荷での植 物油の CO, THC 及びスモークを低減について実験を 行った結果，以下のことが明らかになった。

1) アシスト噴射により，低負荷での植物油の CO , THC 及びスモークを低減することが可能である. 低減 幅はアフター噴射効果約 $30 \%$ ，プレ噴射効果 $50 \%$ 以 上である。

2）噴射量について，プレ噴射の場合，少量噴射が望 ましく, アフター噴射の場合, 多量噴射が効果的であ る.

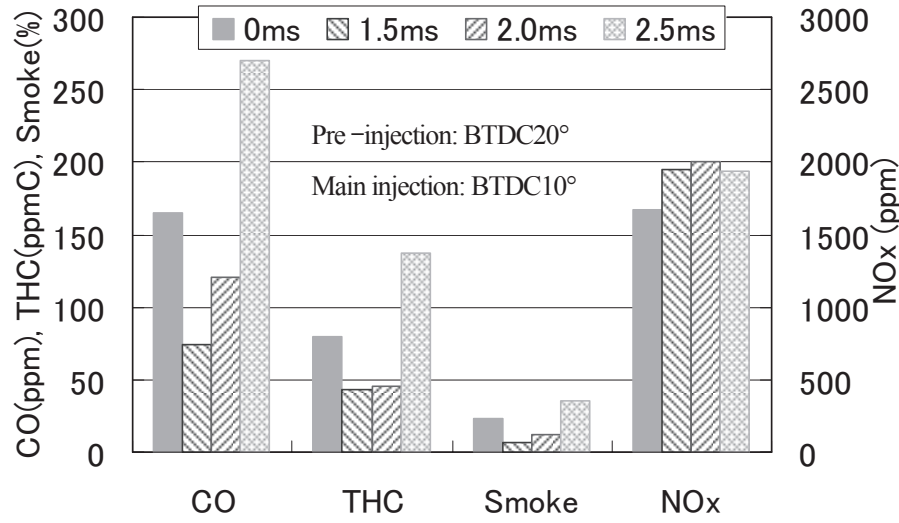

Fig. 9 CO, THC, Smoke and NOx vs. Pre-injection Period

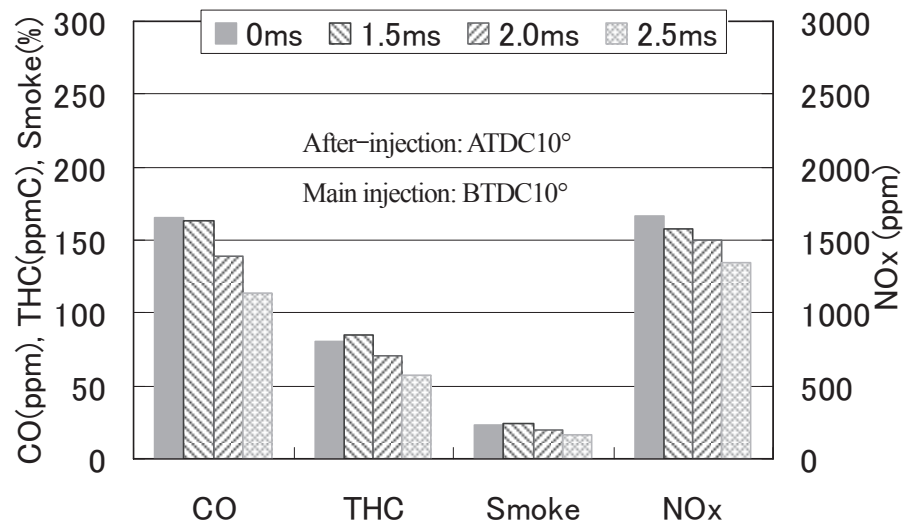

Fig. 10 CO, THC, Smoke and NOx vs. After-injection Period

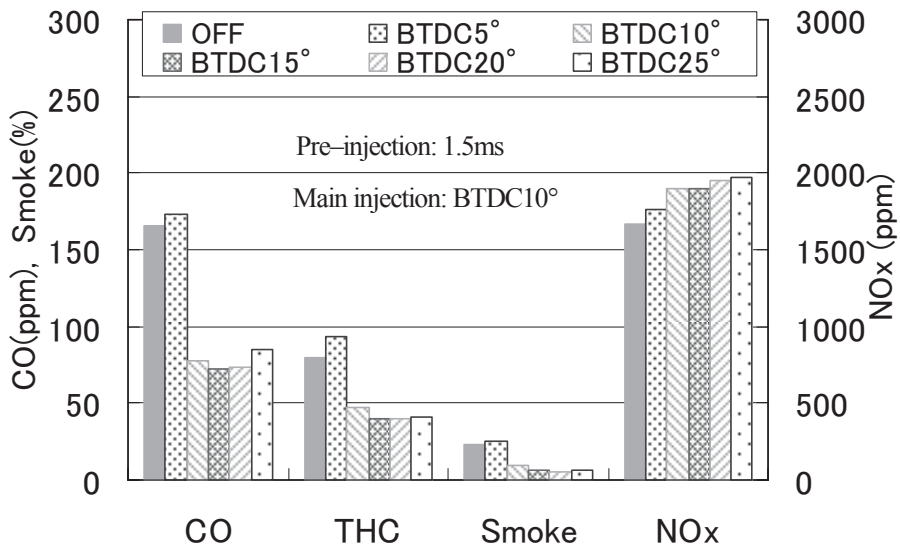

Fig. $11 \mathrm{CO}$, Smoke and NOx vs. Pre-injection Timing

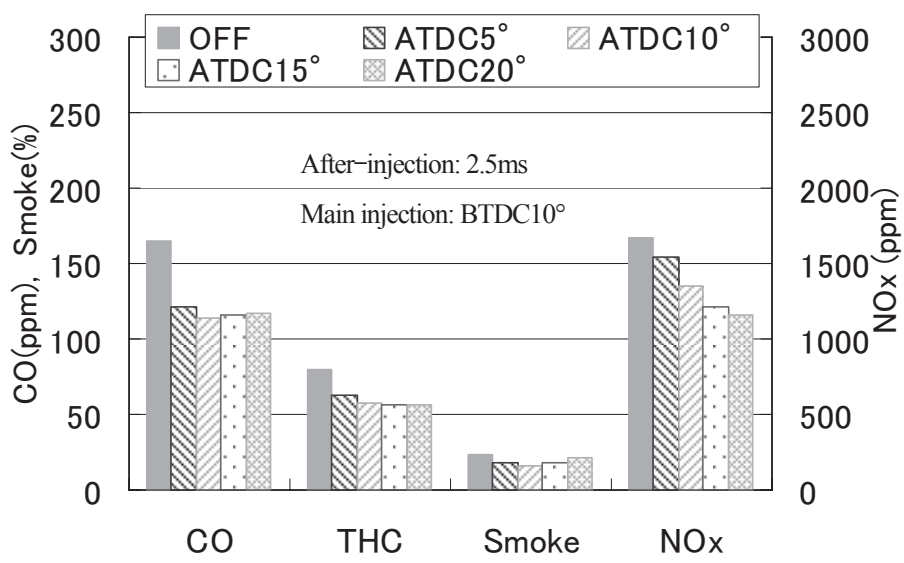

Fig. $12 \mathrm{CO}$, Smoke and NOx vs. After-injection Timing 
3）噴射タイミングについて,プレ噴射はメイン噴射 之離すのが効果的で，アフター噴射はメイン噴射から 約 10 離すのが望ましい.

以上の結果からアシスト噴射により，低負荷での植 物油の CO，THC 及びスモークの低減が可能であるこ とが分かった. しかし，スモークが低減していても低 負荷でエステル化していない植物油を使用すると, SOF 等の他の PM 成分が懸念されるが，その詳細は今 後の課題として検討していきたい.

アシスト噴射は，エンジン回転数と負荷率に依存 せず噴射圧力，噴射時期及び噴射パターンを制御す ることが可能である. また小型化が可能で, 安価で 比較的改造が少なく既存のエンジンへの適用が容易 などのメリットがある. 今後, このデータを活かし て, 自動制御の最適化についても検討していきたい.

\section{謝辞}

本研究は独立行政法人鉄道建設・運輸施設整備支援 機構「運輸分野における基礎的研究推進制度」により 実施しました。ここに謝意を表します。

\section{参考文献}

1) 西尾他 7 名, 第 79 回マリンエンジニアリング講演集, (2009), 19-20.

2) 徐他 3 名, 機械学会関東支部 16 期講演集, (2010), 371-372.

3) 西尾他 8 名, マリンエンジニアリング学会誌, Vol.45, No.5(2010), 120-126.

4) 小川他 4 名, 自動車技術会論文集, Vol.39, No.1 (2008), 101-106.

5) 神谷他 5 名, 自動車技術会論文集, Vol.38, No.2 (2007), 161-166.

6) 神谷他 5 名, 自動車技術会論文集, Vol.40, No.3 (2009), 711-716. 